\title{
Development of Facility and Infrastructure Administration Module LC5E Improve Student Learning Outcomes
}

\author{
Lailatul Maulindah \\ Mohammad Arief \\ Pendidikan Administrasi Perkantoran Universitas Negeri Malang \\ Mariani Setijo Oetami \\ SMK Negeri 1 Pasuruan \\ E-mail:mohammad.arief.fe@um.ac.id; lailatulmaulindah@gmail.com
}

\begin{abstract}
The purpose of this research are generating module of administration facilities and infrastructure based learning cycle 5E for students of SMK/MAK grade XII Office Administration skill program, determine the feasibility module of administration facilities and infrastructure based learning cycle $5 E$ through expert validation test modules, subject matter experts, and students, also to determine improving student learning outcomes before and after using the module of administration facilities and infrastructure based learning cycle 5E. The result of research show that the development result module is deemed very feasible to be used in the learning activities and the average student score after using the development result module also experience an increase.
\end{abstract}

Key words: module, learning cycle, facilities infrastructure

Education is one of factors that affect national improvement. Advanced states will also be judge by education aspect. Education has an important role in the producing quality human resources process (Winter, 2011; Pfeffer, 2015; Bij, et al., 2016; Perri, 2016; Volosovets, et al., 2017). According to Legislation Number 20 of 2003 that education is a conscious and planned effort undertaken by teachers to create an atmosphere of learning and learning process so that student can actively develop the potential possessed and skills needed in community life. Recognizing the importance of education, the governments continues to make improvement and perfectionto curriculum applied in Indonesia. Currently, the government apply 2013's curriculum as a reference for education in Indonesia.

The implementation of 2013's curriculum makes some changes and additions to subject that must be taken by student. The subjects of SMK/MAK for 2013's curriculum are devided into 3 categories, C1, C2 and C3. In the competence of Office Administration, Facilities and Infrastructure Administration is a latest subject in C3 category. Application of Facilities and Infrastucture Administration subject is still fairly new for both teachers and student, they struggle in finding source of reference that can be used as learning and teaching material. The unavailability of teaching materials in 2013's syllabus is a challenge for teachers in 
finding suitable reference source (Budi, 2014; Waybin, 2014; Permana, 2015; Anjasari, 2015). This makes learning process in classroom felt less effective to build a critical thingking pattern of student because there is no source of learning that become student's conviction in understanding learning process.

Based from problem above, the existence of teaching materials that can be used by teachers and students in the learning process that is adjusted to 2013's curriculum felt necessary. Lestari (2013: 5) states that 'teaching materials have two types which is hardcopy and softcopy. A hardcopy materials that are often encountered include handouts, books, modules, brochures, and student's worksheets". In this study, researchers developed hardcopy material as a form of learning modules. The module is one of the learning resources that can be used as a learning material for both teachers and students (Somayasa, et al., 2013; Lestari, 2013; Pratiwi, 2015; Hildawati, 2015). Hamdani (2011 : 219) said that the module is a learning tool designed systematically and interesting to achieve the competencies expected and can be used independently. Modules can be used to improve student's independence in learning and assist tearchers in delivering learning materials easly (Shahidayanti, 2012; Lusia, 2013; Lestari, 2013; Widyaningrum, 2013).

Modules designed with various instructional models tailored to the basic competencies to attract student's attention, one of them by using $5 \mathrm{E}$ learning cycle model. Dasna (2006) argues that the 5E learning cycle model emphasizes student to be actively involved in every learning process so that learning is more studentcentered. 5E learning cycle divides the process of learning activities into several stages of activities organized systematically so that student can achieve the competencies that have been determined. 5E learning cycle model motivates student to be interested in topucs through several stages of learning activities including engagement stage, exploration stage, explanation stage, elaboration stage, and evaluation stage (Kilavuz, 2005; Dasna, 2006; Cholistyana, 2014; Sari, 2014).

The 5E learning cycle model refers to constructivist paradigm that emphasizes the importance of student to built their own knowledge by being actively involved in every learning process (Kilavuz, 2005; Dasna, 2006; Bybee, 2006; Ozeke, 2009; Soebagio in Agustyaningrum, 2011). Bybee (2006) said that 5E learning cycle is a constructivitst-based science learning model. Soebagio (in Agustyaningrum, 2011) also said that 5E learning cycle is a learning model that drives student to find their own concepts, prevent the occurrence of misconceptions, and provide opportunities for student to apply the learning concept in new situation. This is mean that learning is based on student, which requires student to understand, processing and find their own knowledge while teacher only acts as a facilitator who provides facilities and create a conducive environment.

Based on description above, the researcher tried to develop learning module of Infrastructure Administration based on 5E learning cycle model. This learning module can be used independently by student and make it easier for teachers and students in every learning process.

The purpose of this research is to 1) produce module Facilities and Infrastucture Administration based on 5E learning cycle for 10 grade of Administration Training 
Office Program Student in SMK/MAK; 2) to know the feasibility of Facilities and Infrastucture Administration module based on 5E learning cycle through validation test of module expert, material experts and students; 3) to know student's improvement by their learning outcomes before and after using Facilities and Infrastucture module based on 5E learning cycle.

\section{METHOD}

Research and development is used to produce a specific product and test the product's effectiveness (Sugiyono, 2015). The model development adopted from Borg and Gall's Development of research (Sugiyono, 2015) which has been modified into eight stages. The research phase is as follows :

Pic 1 Research Stage of Module Development

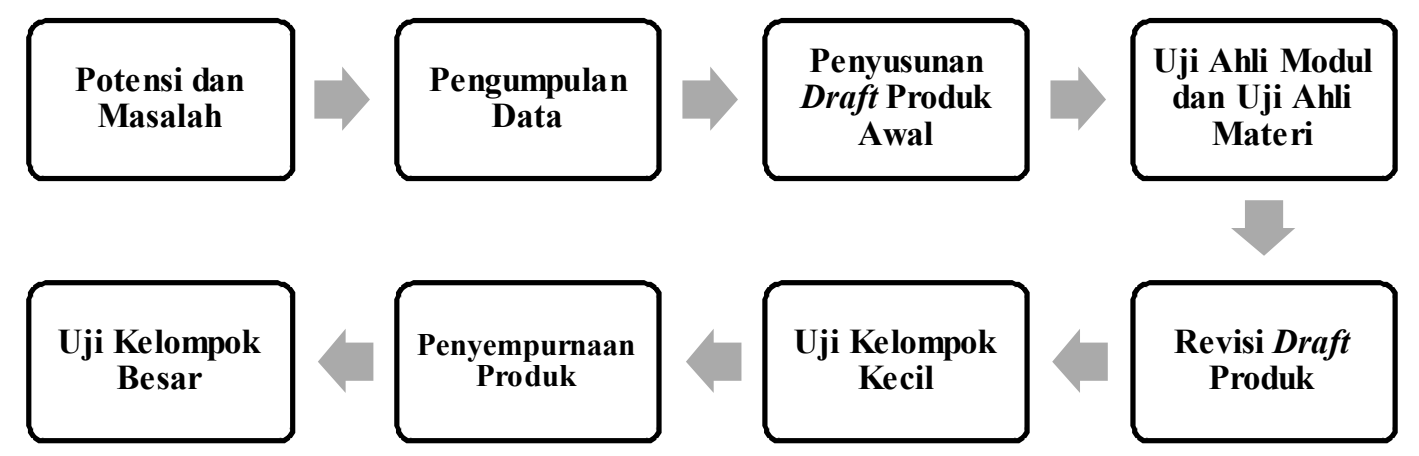

Source : modified from Borg and Gall's Model

The research was conducted at SMK Negeri 1 Pasuruan on 10 grade student of Administration Training Office Program (APK). Trial subject consist of small group test and large group tests. The small group test was conducted to 6 students of 12 grade APK 2, while the big group conducted to 36 student of 12 grade APK 1 . Expert module validation was done by lecturer of Education Study Program of Administration Universitas Negeri Malang who have capability of making teaching materials, while validation of material experts submitted by 12 grade's teachers of Facilities and Infrastucture Administration subject of APK in SMKN 1 Pasuruan.

Data collection instrument in this study is divided into three which are interview guides, questionnaires and documentation. The measurement scale used to calculate the result of questionnaires like Likert with each category (1) Score 4 means veru valid/strongly agree/ very decent, (2) score 3 means valid/ agree/ decent, (3) score 2 means quite valid/ quite agree/ adequate enough, and (4) Score 1 means less valid/ less agree/ less feasible (Sugiyono, 2015). Data analysis techniques consist of qualitative techniques and quantitative techniques. Qualitative techniques use to analyze interview data and written notes in the form of comments and suggestions provided by module experts, material experts and students when filling out the questionnaire. Quantitative techniques are use to analyze quantitative data obtained from questionnaires and students learning outcomes before and after using the development result module. The difference of learning outcomes of student's cognitive aspect before and after using that module 
has been developed, shown by student's average score discrepancy before and after using 5E learning cycle of Facilities and Infrastucture Administration module.

\section{RESULT \& DISCUSSION}

\section{Result}

This research was conducted to generate Facilities and Infrastucture Administration module based on 5E learning cycle for 12 grade student of second semester in Administration Expertise Program at SMK/MAK. The subject's topic that develop in a modul is facilities and infrastructure elimination report. That module development is made up of two guidance for teacher and student. The teacher's handbook module comes with an key for all questions contained in the student module. The development of Infrastructure Administration module uses 5E learning cycle model. The module expert was handed over to Heny Kusdiyanti, while the material expert was performed by Mariani Setijo Oetami. The validation results for quantitative of module expert and material expert are as follows

Table 1. Quantitative Validation Result of Module and Material Expert

\begin{tabular}{|c|c|c|c|c|c|c|c|}
\hline \multirow{3}{*}{ No } & \multirow{3}{*}{ Keterangan } & \multicolumn{3}{|c|}{ Ahli Modul } & \multicolumn{3}{|c|}{ Ahli Materi } \\
\hline & & \multicolumn{2}{|c|}{ Skor } & \multirow{2}{*}{$\begin{array}{l}\text { Persenta } \\
\text { se } \\
\%\end{array}$} & \multicolumn{2}{|c|}{ Skor } & \multirow{2}{*}{$\begin{array}{l}\text { Persenta } \\
\text { se } \\
\% \\
\end{array}$} \\
\hline & & $\sum \mathbf{X}$ & $\sum \mathrm{X} 1$ & & $\sum X$ & $\sum X 1$ & \\
\hline 1 & Kelayakan Isi & 29 & $\overline{40}$ & 72,5 & 36 & $\overline{40}$ & 90 \\
\hline 2 & Kelayakan Penyajian & 43 & 48 & 90 & 44 & 48 & 92 \\
\hline 3 & Kelayakan Bahasa & 41 & 52 & 79 & 46 & 52 & 88 \\
\hline 4 & $\begin{array}{l}\text { Kelayakan } \\
\text { Kegrafikaan }\end{array}$ & 34 & 40 & 85 & 38 & 40 & 95 \\
\hline \multicolumn{2}{|c|}{ Total Perolehan } & 147 & 180 & 82 & 164 & 180 & 91 \\
\hline \multicolumn{2}{|c|}{ Kriteria } & \multicolumn{3}{|c|}{ Sangat Valid } & \multicolumn{3}{|c|}{ Sangat Valid } \\
\hline
\end{tabular}

(Source : Quantitative Validation Result of Module and Material Expert, 2017)

Based on the validation results of module expert obtained $82 \%$ of atotal percentage, where the number indicated that nodule product has a very valid/ very feasible criteria to use with unnecessary revised information, and for validation result of material expert obtained $92 \%$ of total percentage, that number also indicated that nodule product has a very valid/ very feasible criteria to use with unnecessary revised information. Qualitative data is obtained from comments and suggestions provided by module expert and material experts. That feedback will be considered in refinement the module products so that can be better. A small group test was conducted to the effectiveness of module that use among student. The subjects of small group test were the 12 grade students consist who have the highest rank, middle and low rank. The results of small group data is divided into two, qualitative and quantitative data. Quantitative data was obtained from the questionnaire score of student responses presented as follows 
Table 2. Quantitative Data Small Group's Test Result

\begin{tabular}{|c|c|c|c|c|c|}
\hline \multirow[t]{2}{*}{ No } & \multirow[t]{2}{*}{ Responden } & \multicolumn{2}{|c|}{ Skor } & \multirow{2}{*}{$\begin{array}{l}\text { Persenta } \\
\text { se } \\
\% \\
\end{array}$} & \multirow[t]{2}{*}{ Kriteria } \\
\hline & & $\sum \mathbf{X}$ & $\sum \mathrm{X} 1$ & & \\
\hline 1 & $\begin{array}{ll}\text { Siswa } 1 & \text { (Mar'atu } \\
\text { Fitamamila) } & \end{array}$ & 87 & 100 & 87 & Sangat Valid \\
\hline 2 & $\begin{array}{l}\text { Siswa } 2 \text { (Septi Syafa'atur } \\
\text { Rosida) }\end{array}$ & 82 & 100 & 82 & Sangat Valid \\
\hline 3 & $\begin{array}{lrll}\text { Siswa } & 3 & \text { (Eka } & \text { Kusnul } \\
\text { Ikhtiarini) } & & \end{array}$ & 91 & 100 & 91 & Sangat Valid \\
\hline 4 & Siswa 4 (Mariatul Qiptiyah) & 83 & 100 & 83 & Sangat Valid \\
\hline 5 & $\begin{array}{lcl}\text { Siswa } & 5 & \text { (Idealisa } \\
\text { Aprisiyahudin) } & \end{array}$ & 90 & 100 & 90 & Sangat Valid \\
\hline 6 & $\begin{array}{l}\text { Siswa } 6 \text { (Febriani Diana } \\
\text { Lestari) }\end{array}$ & 94 & 100 & 94 & Sangat Valid \\
\hline Tot: & l Perolehan & $\begin{array}{l}52 \\
7\end{array}$ & 600 & 87,8 & Sangat Valid \\
\hline
\end{tabular}

(Source : Quantitative Data Small Group's Test Result, 2017)

Based on the results of questionnaires responses of small group test students obtained $87,8 \%$ total percentage, meaning the module has a very valid / very feasible criteria to use to use with unnecessary revised information. Qualitative data obtained from comments and suggestions provided by students and then will be a consideration in improving the module products so can be more perfect.

Further data from all respondents are made into one and analyzed by using descriptive analysis technique percentage, that is technique to convert quantitative data into percentage then interpreted with sentence which is qualitative. The following analysis of data from all respondents

Table 3. Data Analysis of Validator and Student Response Results

\begin{tabular}{llll}
\hline No. & Validator & $\begin{array}{l}\text { Persenta } \\
\text { se }\end{array}$ & Kriteria \\
\hline 1 & $\begin{array}{l}\text { Ahli Modul (Dr. Heny Kusdiyanti, S.Pd, } \\
\text { M.M) }\end{array}$ & 82 & Sangat Valid \\
\hline 2 & Ahli Materi (Mariani Setijo Oetami, S.Pd) & 91 & Sangat Valid \\
\hline 3 & Siswa 1 (Mar'atu Fitamamila) & 87 & Sangat Valid \\
\hline 4 & Siswa 2 (Septi Syafa'atur Rosida) & 82 & Sangat Valid \\
\hline 5 & Siswa 3 (Eka Kusnul Ikhtiarini) & 91 & Sangat Valid \\
\hline 6 & Siswa 4 (Mariatul Qiptiyah) & 83 & Sangat Valid \\
\hline 7 & Siswa 5 (Idealisa Aprisiyahudin) & 90 & Sangat Valid \\
\hline 8 & Siswa 6 (Febriani Diana Lestari) & 94 & Sangat Valid \\
\hline Rata-rata & $\mathbf{8 7 , 5}$ & Sangat Valid \\
\hline Source
\end{tabular}

Source : Data Analysis of Validator and Student Response Results, 2017

Based on a table above it can be concluded that development 5E learning cycle of Learning and Infrastructure Administration module is considered very 
valid / very suitable to be used in the learning process in the classroom especially for 12 grade APK students at SMK Negeri 1 Pasuruan with an average percentage of $87,5 \%$ seen from the validation results of module experts, material experts, and students as a small group test subjects.

A large group test was conducted to confirm the improvement of student learning outcomes determined from differences in learning outcomes before and after using the $5 \mathrm{E}$ learning cycle of Facility and Infrastructure Administration module. Comparison of learning outcomes is seen on the students' scores taken from the posttest average score at the basic competencies establish the storage and maintenance of facilities and infrastructure's report owned by the Facility and Infrastructure Administration's teacher for the credit before using the module and the average value taken from the student's posttest credit after using the 5E Learning Cycle of Facility and Infrastructure Administration module

The big group test was conducted on the students of 12 class APK 1 which add up to 36 students with 3 meetings each held for $3 \times 45$ minutes. Comparison of student learning outcomes between before and after using the Facility and Infrastructure Administration module based on 5E Learning Cycle is as follows

Table 4. Comparison of Student Learning Results Before and After Using Modules

\begin{tabular}{llll}
\hline & $\begin{array}{l}\text { Nilai } \\
\text { Menggunakan } \\
\text { Hasil Pengembangan }\end{array}$ & $\begin{array}{c}\text { Sebelum } \\
\text { Modul }\end{array}$ & $\begin{array}{l}\text { Nilai } \\
\text { Menggunakan } \\
\text { Hasil Pengembangan }\end{array}$ \\
\hline $\begin{array}{l}\text { Jumlah Nilai } \\
\text { Siswa }\end{array}$ & Seluruh & 3220 & 3357 \\
Nilai Rata-Rata Kelas & 89,44 & 93,25 \\
\hline $\begin{array}{l}\text { Jumlah Siswa } \\
\text { Hadir }\end{array}$ & 36 & 36 \\
\hline
\end{tabular}

Source : Comparison of Student Learning Results Before and After Using Modules, 2017

Based on the data above the average score of students before using the 5E Learning Cycle Facility and Infrastructure Administration module from the teacher is 89.44, while the average score of students after using the 5E Learning Cycle of Facility and Infrastructure Administration module obtained from posttest value is 93.25. The average value of student learning outcomes have increased between before and after using the development of the module by the difference of 3.81. Thus, prove that the module of Facility and Infrastructure Administration based on $5 \mathrm{E}$ Learning Cycle is very feasible to improve student learning outcomes and can be used as teaching materials in classroom learning activities

\section{Discussion}

This research produces instructional materials, namely the Facility and Infrastructure Administration Module based on 5E Learning Cycle on elimination of facilities and infrastructure administration subject for the 12 grade. Module development using 5E Learning Cycle model. The 5E learning cycle model is based 
on a constructivist paradigm that emphasizes the importance of building student's knowledge by being actively involved in the learning process (Kilavuz, 2005, Dasna, 2006; Bybee, 2006; Ozeke, 2009; Soebagio (in Agustyaningrum, 2011)). 5E learning cycle model guides students in finding their own concepts by engaging directly and actively in each learning stage (Dasna, 2006). Students using the 5E learning cycle model to understand the concept of subject matter better than students who did not use the $5 E$ learning cycle model (Kilavuz, 2005).

The 5E learning cycle model effectively used to help students enjoy every learning activity, understand and apply concepts in real situations (Kilavuz, 2005; Ozeke, 2009). Soebagio (in Agustyaningrum, 2011) also said that "5E learning cycle is a learning model that enables students to find their own concepts, prevent the occurrence of misconceptions, and provide opportunities for students to apply the concepts learned in new situations". There are five stages in 5E learning cyce model such as engagement stage, exploration stage, explanation stage, elaboration stage, and evaluation stage (Kilavuz, 2005; Dasna, 2006; Cholistyana, 2014; Sari 2014). The first stage is the engagement stage, in this stage the teacher seeks to generate and develop student interest and curiosity about the topic to be studied by asking questions about daily life (Cholistyana, 2014). In this stage students are asked to analyze an adjacent phenomenon by answering the short question presented and related to the phenomenon. Student responses by answering questions, will be identified by the teacher about the presence / absence of misconceptions on students. Teachers should build relationships between students' daily experiences with learning topics to be discussed (Wena, 2010). This stage will help students to connect with the initial knowledge that students have (Kilavuz, 2005).

The second stage is exploration stage. At this stage, the teacher explores the student's initial concept by making observations, making small notes, then communicating them. Problems that are found, controlled, interpreted, then make allegations and others are done by teachers and students together (Panggabean, et al, 2007). At this stage students are formed into small groups and given the opportunity to work together without direction from the teacher (Cholistyana, 2014). In this study, students are asked to read an article relating to the administrative material of the report on the removal of facilities and infrastructure, then ask questions related to the article in small groups. Lawson (in Dahar, 2011) explains that in this stage students are given the opportunity to speak their own ideas and give reasons why they are giving that idea.

The third stage is the explanation stage or the presentation stage of the material. Teachers are required to encourage students to explain a concept with their own group / thought critically (Cholistyana, 2014). With the discussion between teachers and students, teachers can provide definitions and explanations of the concepts discussed by using the previous student's explanation for discussion (Wena, 2010). Teachers collect information from students relating to experience at the exploration stage aiming to observe, recognize, and explain new concepts (Panggabean, et al, 2007).

The fourth stage is the elaboration stage. At this stage students apply the concepts and skills that have been studied in different contexts. (Cholistyana, 2014). In this study, students are sent to work on problems related to the previous 
stage, which aims to develop the knowledge that has been built by students. By applying the knowledge, students develop the learning materials in the exercise questions at this stage. If this stage is delivered well by the teacher then the students' learning motivation will increase. Increased student learning motivation can certainly encourage the improvement of student learning outcomes (Wena, 2010).

The fifth stage is the evaluation stage. In this stage the teacher can observe which students understand to apply new concepts. Evaluation results can be used as an evaluation by teachers about teaching and learning activities, whether it is running very well, good, good enough, or still less (Cholistyana, 2014). Thus the students will be able to know the progress and shortcomings in the learning process that has been done. The results of this study is supported by previous research conducted by Widyaningrum (2012) which shows that the achievement of student learning outcomes has increased significantly in the medium category after using the module in spreading. Research by Shahidayanti (2012) also shows that by using learning modules, student learning outcomes increased to $67.74 \%$. In addition, research conducted by Somayasa (2013) shows that the learning module can improve student learning outcome of 76.62. This research is also supported by research from Anjasari (2015) which shows that 5E learning cycle model can improve student learning outcomes and effectively used as learning materials independently. Kilavuz (2005) also revealed that by using the $5 \mathrm{E}$ learning cycle model, students showed statistical developments in attitudes and skills in understanding the concept of learning materials. In every learning process, students will actively solve every problem that exist in each stage of $5 \mathrm{E}$ learning cycle. This makes students able to explain the material better than the students who learning process without 5E learning cycle (Sumarni, 2010). Students use their own ideas when using the 5E learning cycle model and it makes students accustomed to explaining the material in their own language.

The difference between this research with other research is, 5E learning cycle model more often used in the field of science research (Dasna, 2006), such as research conducted by Kilavuz, 2005; Sumarni, 2010; Widyaningrum, et al. 2013; Lusia, 2013; And Cholistyana, 2014. The present study shows that the 5E learning cycle model can be used not only in science but also in other scope such as social sciences. This is reinforced by previous research such as Hildawati, 2015. She said that "Development of Learning Accounting Module With 5E Learning Cycle Model contain Nation Character Value For Students SMK Negeri 1 Turen". 5E Learning cycle module can be used in the field of social science to improve student learning outcomes. Especially in every stage of learning, students are lead to participate actively in learning and dare to express their own ideas. In other words, students understand the material learned by using their own language.

Facilities and Infrastructures Administration module based on 5E learning cycle can improve student learning outcomes because: (1) 5E learning cycle model can improve students' learning motivation by actively participating in every learning activity (Cholistyana, 2014); (2) The 5E learning cycle model enables students to explain the material better using their own language (Sumarni, 2010); (3) Kilavuz, 2005 said that "The first stage in the 5E learning cycle model aims to attract students' attention, know the initial knowledge of the students and relate it 
to the topics to be studied". The important thing in this stage is attract student's curiosity about the topic. Curiosity can be achieved by asking students questions about phenomena related to the material to be discussed. Implementation in Facilities and Infrastructures Administration module based on 5E learning cycle is students are given some interesting questions and relate to their the daily life ; (4) Kilavuz, 2005 said that during the exploration stage, students are given the opportunity to work in small groups to do some questions without instruction and assistance from the teacher. At this stage, students are given the opportunity to explore the material through student-centered activities, observe, and keep the data obtained (Dasna, 2006).

In the 5E Learning Cycle and Infrastructure Administration Module, students are asked to look on interesting article related to the removal materials and infrastructure report, then answer the questions on the worksheet; (5) Dasna, 2006 said in the explanation stage, students are given an opportunity to explain the concept comprehension result from the exploration stage. At this stage students are encouraged to explain the concept with its own words. Implementation in the 5E Learning Cycle of Infrastructure Administration Module and provide a description or explanation of administrative materials on the removal of facilities and infrastructure report; (6) Kilavuz, 2005 said that in the elabroation stage, students get the opportunity to apply the concepts and skills they possess to new situations but still on the same subject. The purpose of the elaboration stage is basically to increase students' understanding of what they know from the material that has been described. The elaboration stage is presented by providing additional activities to the students to extend the ideas relating to the concepts that students have built. Implementation in the $5 \mathrm{E}$ Learning Cycle's Infrastructure and Infrastructure Administration Module is by presenting practical exercises and practice activities to develop students' knowledge; (7) Dasna, 2006 said that in the evaluation stage, students are given questions that aims to know and measure how far the ability and understanding of students to the administrative material on the removal of facilities and infrastructure report. Implementation of 5E Learning Cycle Infrastructure Based Infrastructure module is to provide a variety of questions related to the material that has been studied by the students.

\section{CONCLUSION \& SUGGESTION}

\section{Conclusion}

Based on this study, it can be said that (1) this research and development produce Facility and Infrastructure Administration Module based on 5E Learning Cycle on the basic competence of elimination of facilities and infrastructure report of 12 grade student of Administration Training Office Program in SMK/MAK; (2) from feasibility aspect of the module experts' validation, material expert and small group test show that the result is very suitable for learning process; (3) modules development can improve student's learning outcomes with higher score after using modules than before using module for 12 grade student of Administration Program consist of teacher guidance modules and student guidance module. 


\section{Suggestion}

Suggestion for the student is they should study the material in the module first at home so that the use of module can be applied well during the learning process, take place as well as the student expected to follow the instruction of the module. Suggestion for teacher that they should become mentor and facilitator for student in learning contents and they must be ready become place to ask if student struggle using module.

\section{REFERENCES}

Agustyaningrum, N. 2011. Implementasi Model Pembelajaran Learning Cycle 5E Untuk Meningkatkan Kemampuan Komunikasi Matematis Siswa Kelas IX B SMP Negeri 2 Sleman. Makalah Seminar Nasional Matematika dan Pendidikan Matematika Jurusan Pendidkan Matematika UNY, 3 Desember 2011, (Online), (http://eprints.uny.ac.id), diakses 14 Mei 2017.

Anjasari, T. D. 2015. Pengembangan Modul Administrasi Sarana dan Prasarana Berbasis Learning Cycle 4E (Untuk Siswa Kelas XII Program Keahlian Administrasi Perkantoran di SMK Negeri 1 Malang). Skripsi tidak diterbitkan. Malang: FE UM.

Bij, T., Geijsel, F.P., \& Dam, G. T. M. 2016. Improving The Quality Of Education Through Self - Evaluation In Dutch Secondary Schools. Journal of Educational Evaluation, (Online). 49:42-50, (http//www.sciencedirect.com), diakses 13 Mei 2017.

Budi, B. S. 2014. Strategi Guru Dalam Menghadapi Kurikulum 2013 Di SMA Negeri 2 Surakarta. Jurnal Ilmu Pendidikan Sosial, (Online), 4 (1), (http://jurnal.fkip.uns.ac.id), diakses 13 Mei 2017.

Bybee, R. W., \& Taylor, J. A. 2006. The BSCS 5E Instructional Model: Origins and Effectiveness. (Online), (http:www.ashg.org), diakses 13 Mei 2017.

Cholistyana, I. E. 2014. Pengaruh Model Learning Cycle 5E Terhadap Hasil Belajar Siswa Pada Konsep Sistem Eksresi. Skripsi tidak diterbitkan. Jakarta: UIN Syarif Hidayatullah.

Dahar, R. W. 2011. Teori-teori Belajar dan Pembelajaran. Jakarta: Erlangga.

Dasna, I.W. 2006. Model Siklus Belajar (Learning Cycle) Kajian Teoritis Dan Implementasinya dalam Pembelajaran Kimia dalam I Wayan Dasna dan Sutrisno (Eds.), Model-Model Pembelajaran Konstruktivistik dalam Pembelajaran Sains Kimia (hlm.69-97). Malang: Jurusan Kimia FMIPA UM.

Hamdani. 2011. Strategi Belajar Mengajar. Bandung: Pustaka Setia. 
Hildawati. 2015. Pengembangan Modul Pembelajaran Akuntansi Dengan Model Learning Cycle 5E Bermuatan Nilai Karakter Bangsa Untuk Siswa SMK Negeri 1 Turen. Skripsi tidak diterbitkan. Malang: Universitas Negeri Malang.

Kilavuz, Y. 2005. The Effects Of Learning Cycle Model Based On Constructivist Theory On Tenth Grade Students Understanding Of Acid-Base Concepts. Thesis. Turki: Middle East Technical University.

Lestari, I. 2013. Pengembangan Bahan Ajar Berbasis Kompetensi (Sesuai dengan Kurikulum Tingkat Satuan Pendidikan). Padang: Akademia Permata.

Lusia, M. T. A. 2013. Pengembangan Modul Fisika Berorientasi Learning Cycle 5E Pada Materi Gerak Kelas VII SMP. Jurnal Inovasi Pendidikan Fisika. 02 (03): 147 - 151.

Ozeke, S. 2009. Connections Between The Contructivist-Based Models For Teaching Science And Music. Journal Procedia Social and Behavioral Sciences, 1: 1068-1072.

Panggabean, Y. 2007. Strategi, Model, Dan Evaluasi: Pembelajaran Kurikulum 2006. Bandung: Bina Media Informasi.

Permana, P. D. 2015. Pengaruh Penerapan Kurikulum 2013 Terhadap Hasil Belajar Mata Diklat Pengelasan Kelas X TKR Di SMK Negeri 1 Sedan Rembang Tahun Ajaran 2013/2014. Skripsi tidak diterbitkan. Semarang: FT UNS.

Perri. T. 2016. Online Education, Signaling, And Human Capital. Journal of Information Economics and Policy, (online) 36: 69-74, (http://sciencedirect. com), diakses 13 Mei 2017.

Pfeffer. F. T. 2015. Equality And Quality In Education. A Comparative Study Of 19 Countries. Journal of Social Science Research, (Online), 51: 350-368, (http://sciencedirect. com), diakses 13 Mei 2017.

Pratiwi, H. N., Sutrisno, \& Wasiti. 2015. Pengembangan Media Pembelajaran emodul Berbasis adobe indesign Untuk Meningkatkan Hasil Belajar Siswa. Jurnal Pendidikan Bisnis dan Manajemen. 1 (2): 100-108, (http://journal.um.ac.id), diakses 13 Mei 2017.

Sari, E. S. 2014. Penerapan Model Pembelajaran Learning Cycle 5E Untuk Meningkatkan Aktivitas Belajar Fisika Siswa Kelas $X$ Keperawatan SMK Kesehatan Probolinggo. Skirpsi tidak diterbitkan. Malang: FMIPA UM.

Shahidayanti, T., \& Dhoruri, A. 2012. Pengembangan Modul Pada Materi Segi Empat Untuk Siswa Kelas VII SMP Berdasarkan Pendekatan Kontekstual Untuk 
Meningkatkan Hasil Belajar Siswa, (Online), (http://eprints.uny.ac.id), diakses 13 Mei 2017.

Somayasa, W., Natajaya, N., \& Candiasa, M. 2013. Pengembangan Modul Matematika Realistik Disertai Asesmen Otentik Untuk Meningkatkan Hasil Belajar Matematika Peserta Didik Kelas X Di SMK Negeri 3 Singaraja. (Online), (http://download.portal garuda.org), diakses 13 Mei 2017.

Sugiyono, 2015. Metode Penelitian Kuantitatif Kualitatif dan R\&D. Bandung: Alfabeta.

Sumarni, W. 2010. Penerapan Learning Cycle Sebagai Upaya Meningkatkan Keterampilan Generik Sains Inferensia Logika Mahasiswa Melalui Perkuliahan Praktikum Kimia Dasar. Jurnal Inovasi Pendidikan Kimia, (Online), 4 (1): 521531. (http://download.portalgaruda.org), diakses 13 Mei 2017.

Undang-Undang Republik Indonesia Nomor 20 Tahun 2003 tentang Sistem Pendidikan Nasional. Kementerian Riset Dan Pendidikan Tinggi. (Online), (http://kelembagaan.ristekdikti.go.id), diakses 13 Mei 2017.

Volosovets, T., Kirillov. I., \& Buyanov. A. 2017 Evaluating The Quality of Preschool Education in Rusia. Journal of Social and Behavioral Sciences, (Online). 237:1299-1303, (http://sciencedirect.com) , diakses 13 Mei 2017.

Waybin, E. F. 2014. Implementasi Kurikulum 2013 Dalam Proses Pembelajaran Di SMK Negeri 3 Yogyakarta. Skripsi tidak diterbitkan. Yogyakarta: FT UNY.

Wena, M. 2010. Strategi Pembelajaran Inovatif Kontemporer: Suatu Tinjauan Konseptual Operasional. Jakarta: Bumi Aksara.

Widyaningrum, R., Sarwanto. \& Karyanto, P. (2013). Pengembangan Modul Berorientasi POE (Predict, Observe, Explain) Berwawasan Lingkungan Pada Materi Pencemaran Untuk Meningkatkan Hasil Belajar Siswa. Jurnal Bioedukasi, (Online). 6 (1): 100-117. (http://download.portalgaruda.org), diakses 13 Mei 2017.

Winters, J. V. 2011. Human Capital, Higher Education Institutions, And Quality of Life. Journal of Regional Science and Urban Economics, (Online). 41 (5): 446454, (http://www.science direct.com), diakses 13 Mei 2017. 